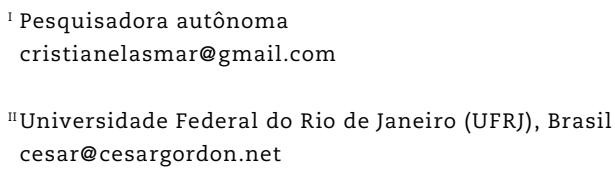

\title{
UM ANTROPÓLOGO DA CIVILIZAÇÃO AMAZÔNICA: ENTREVISTA COM STEPHEN HUGH-JONES
}

É com muita satisfação e expectativa que apresentamos aos leitores esta entrevista com Stephen Hugh-Jones, um dos mais interessantes e criativos antropólogos da sua geração e um dos nomes mais importantes da etnologia americanista. A satisfação se deve ao fato de que Hugh-Jones completa, neste ano de 2015 , seu $70^{\circ}$ aniversário de uma vida dedicada à antropologia, em particular aos povos indígenas da região do noroeste amazônico. A expectativa é a de que a entrevista, juntamente com os três artigos que a sucedem, possa ensejar novas apropriações e discussões de sua rica e variada obra, cuja relevância não se limita ao círculo de especialistas em Amazônia, tendo alcance antropológico geral.

A entrevista que se segue faz parte de uma série mais longa de conversas com Hugh-Jones, iniciadas em Cambridge em 2009 e que prosseguiram em outros encontros no País de Gales, na França e no Brasil, já em 20I2. No total, foram quase quatro horas de gravação, em que Hugh-Jones falou sempre com o vigor e o entusiasmo de um iniciante. Uma primeira parte dessas conversas foi publicada recentemente na R@U: Revista de Antropologia da UFSCar (volume 6, número I, 20I4) e versa sobre os anos de formação, a infância, o despertar da vocação antropológica, as influências intelectuais, sua relação com seus colegas britânicos e com Edmund Leach. Aqui, Hugh-Jones faz um balanço do campo da etnologia indígena na Amazônia e do seu próprio trabalho em parceria com Christine Hugh-Jones. Dialogando com alguns dos principais autores 
americanistas e melanesistas, enfatiza a necessidade de que os modelos antropológicos de descrição dos povos ameríndios façam jus à complexa variedade de suas formações sociais e cosmológicas.

Stephen Hugh-Jones nasceu a 20 de setembro de 1945 em Poole, cidade portuária no litoral sul da Inglaterra. Em função do trabalho do pai, que era médico, passou parte da infância na Jamaica, experiência que o marcou profundamente e contribuiu para despertar a vocação que, anos depois, o conduziria à carreira em antropologia. O desejo de estudar os índios da América do Sul foi responsável por um encontro fundamental: Edmund Leach, então professor do King's College de Cambridge, onde Hugh-Jones fez toda sua formação acadêmica e posteriormente, professor e fellow, veio a lecionar. Sob orientação de Leach, ele foi um dos primeiros antropólogos britânicos a estudar populações ameríndias, juntando-se a David Maybury-Lewis e Peter Rivière que o antecederam de pouco, e Christine Hugh-Jones, sua mulher e companheira inseparável de aventuras existenciais e intelectuais. Por intermédio de Leach, Hugh-Jones encontrou a segunda de suas grandes referências antropológicas: Claude Lévi-Strauss. As influências do estruturalismo lévi-straussiano se notam desde o primeiro livro, The palm and the pleiades, publicado em I979, mesmo ano em que veio à luz From the milk river, de Christine, dois trabalhos inovadores, e que se completam mutuamente, sobre organização social, ritual, mitologia e o complexo simbolismo dos Barasana, da região do Rio Uaupés no noroeste amazônico.

Apesar da grande dívida teórica para com o estruturalismo, o trabalho de Hugh-Jones foi fruto também de uma inesgotável curiosidade empírica e de uma notável abertura intelectual. Tudo isso resultou em uma antropologia instigante e indisciplinada, que nunca se acomodou diante de teorias e modelos analíticos consagrados. Pelas mesmas razões, Hugh-Jones esteve quase sempre à frente dos principais debates antropológicos, inaugurando a investigação de muitos temas e abordagens que só posteriormente adentrariam o mainstream da disciplina, principalmente no campo da etnologia indígena. Entre eles, podemos mencionar os estudos sobre ritual; a atenção às diferentes modalidades e lógicas do xamanismo; a questão da codificação mitológica das relações entre índios e brancos; a circulação de dinheiro, consumo e trocas comerciais interétnicas; a discussão sobre a aplicação e as implicações da noção lévi-straussiana de casa (maison) e do rendimento da noção maussiana de dádiva no contexto indígena sul-americano; a análise simbólica dos objetos e da cultura material na vida indígena; a descrição sofisticada dos sistemas onomásticos.

Agora septuagenário, Hugh-Jones está oficialmente aposentado e vive com Christine em uma agradável casa de campo no interior do País de Gales. Engana-se, porém, quem o imaginar inativo. Com extraordinária energia, 
mantém plena atividade física e intelectual, escrevendo, proferindo palestras e voltando regularmente ao campo na Amazônia, onde continua a lidar com temas atuais e caros aos índios, além de se engajar em seus projetos políticos e culturais.

Os três artigos inéditos que se sucedem revigoraram e avançam muitos dos debates teóricos da etnologia contemporânea que interessam às ciências sociais como um todo. No primeiro deles Hugh-Jones aborda a complexidade recursiva da cosmologia do noroeste amazônico por meio da análise de um conjunto de mitos sobre a origem da noite. No segundo, Geraldo Andrello, Antonio Guerreiro e Hugh-Jones delineiam questões e implicações teóricas e etnográficas que emergem da comparação entre duas importantes regiões amazônicas: o alto Rio Negro e o alto Xingu. Finalmente, Mauro W. B. Almeida, que teve a oportunidade de ser orientado por Hugh-Jones em Cambridge, inspirado por seu professor e colega, parte de diferentes modalidades de escrita para discutir a pertinência de se falar em matemática indígena.

Assim, esperamos que, em seu conjunto, entrevista e artigos possam dar aos leitores uma boa amostra do trabalho de Hugh-Jones, convidando a novos e futuros diálogos.

Cristiane Lasmar. Agora que conhecemos as origens de seus interesses antropológicos, sua formação e trajetória acadêmica, gostaríamos de enfocar questões etnográficas e teóricas da etnologia ameríndia, sua grande paixão intelectual. Voltemos então aos índios amazônicos, mais especificamente aos índios do Rio Uaupés e da região do alto Rio Negro. Podemos dizer que eles ocupam uma posição específica na paisagem amazônica. Você já havia observado que a mitologia dos índios do Uaupés apresentava alguns problemas para o grande empreendimento de análise que Lévi-Strauss realizou, e por isso mesmo acabaram não tendo espaço em nenhum dos volumes das Mitológicas. Como você vê essa especificidade, e quais seriam as consequências teóricas disso no campo dos estudos ameríndios?

Stephen Hugh-Jones. Quando eu e Christine Hugh-Jones voltamos de nossa primeira estada no campo entre os Barasana da região do Uaupés colombiano, em I97I, participamos de seminários nos quais tivemos oportunidade de apresentar a audiências britânicas parte de nosso trabalho. A resposta de alguns estudiosos que nunca haviam tido experiência com índios amazônicos foi de ceticismo. Disseram que tudo aquilo que relatávamos parecia uma invenção muito inteligente, mas dos antropólogos e não dos índios. Essa era, aliás, uma crítica que se fazia ao estruturalismo, uma das maiores críticas a Lévi-Strauss, muito em conformidade com a tradição empirista britânica. Sua obra seria um grande puzzle intelectual que o antropólogo jogava com a vida e o pensamento de outros povos. Nesse tom, a crítica ao nosso trabalho, meu e de Christine, 
era a de que caíramos em uma espécie de abstratismo, ou seja, os críticos sugeriam que nenhum índio nos havia dito nada daquilo, e que nós havíamos juntado pequenas peças de informação para criar sistemas intelectuais e lógicos um tanto inverossímeis. Vejam, porém, que ironia, quando recentemente estive no Pirá-Paraná para a elaboração de um filme, fiquei encantado ao ver um diagrama feito por um xamã barasana para ser usado em um programa de etnoeducação. Esse desenho era fundamentalmente um sumário diagramático de tudo o que eu e Christine havíamos descrito em nossos livros décadas atrás! (Hugh-Jones, C., I979; Hugh-Jones, S., I979). O que estou dizendo é que aquilo que nossa audiência supunha ser uma construção artificial nossa (influenciados por Lévi-Strauss), sempre foi, e ainda é, absolutamente explícito e consciente nas representações elaboradas pelos próprios índios do Uaupés.

C.L. Sim, isso demonstra a coerência entre a abordagem estruturalista e o simbolismo e a cosmologia dos índios da família tukano oriental. Mas o que dizer de certas características etnográficas da região do noroeste amazônico e do Uaupés que, a princípio, parecem destoar de boa parte das descrições que os antropólogos fizeram de outros povos indígenas em outras regiões amazônicas?

S.H-J. É curioso que, até bem recentemente, eu me sentia numa posição um tanto peculiar em relação a alguns de meus colegas etnólogos amazonistas. Não que eles, diferentemente das nossas primeiras audiências britânicas, desacreditassem do que eu e Christine escrevemos sobre os índios do Uaupés; mas parecia haver um certo consenso americanista segundo o qual era possível fazer generalizações sobre os povos indígenas da Amazônia, ao passo que o Uaupés seria uma espécie de exceção discrepante. Por exemplo, Philippe Descola (200I) argumentou, não faz muito tempo, que não há na Amazônia o que ele chama de heterossubstituição. Isso quer dizer que, apesar de encontrarmos trocas de humanos por humanos ou de objetos por objetos - homossubstituição -, não podemos encontrar, na região amazônica, trocas em que humanos podem ser substituídos por objetos ou animais - como no caso do preço da noiva na Nova Guiné. ${ }^{\mathrm{I}} \mathrm{A}$ certa altura, Descola menciona o Uaupés como uma região em que esse tipo de troca ocorre, mas sugere que não se trata de algo muito explícito, aparecendo somente nas interpretações elaboradas que os antropólogos fazem do discurso simbólico indígena. Eis um exemplo de alguém expressando certa dúvida sobre o que descrevemos para o contexto do Uaupés. $\mathrm{Na}$ verdade, essas ideias são explicitamente formuladas pelos índios, como se pode ver em meu artigo sobre os objetos (Hugh-Jones, 2009).

Cesar Gordon. Apesar de todos os avanços nas pesquisas de antropologia ameríndia, parece, então, difícil escapar a uma visão das sociedades amazônicas como coletivos frouxamente estruturados, nos quais a diferenciação interna é 
pouco marcada, há baixa produtividade sociológica dos objetos, não há riqueza e, portanto, a noção de troca maussiana não se aplica.

S.H-J. Todo antropólogo tem como primeiro ponto de referência sua própria sociedade e como segundo ponto de referência a sociedade que estuda. O que vim a perceber é que, olhando, por exemplo, os trabalhos de Eduardo Viveiros de Castro, de um lado, e os trabalhos de Joanna Overing e seus alunos, de outro, embora saibamos que eles estão, em larga medida, em posições opostas, ambos não deixam de ter um ponto de vista comum. Eles constroem suas generalizações sobre a Amazônia de uma mesma perspectiva, que é a de sociedades de pequena escala, cognáticas, idealmente endógamas, que se constituem a partir de um exterior dramático. Para Joanna Overing, esse exterior é um perigo que se busca evitar, e para Eduardo Viveiros de Castro é uma extensão última do socius. E neste último caso a predação é a forma prototípica da relação social e não a produção do parentesco, como o é para Joanna Overing. Fato é, porém, que os dois modelos partem do mesmo ponto, do mesmo perfil de sociedade amazônica em que a segmentação ou estruturação interna é pouco relevante. Em sua introdução a The anthropology of love and anger, por exemplo, Joanna Overing (Overing \& Passes, 2000) afirma que os índios amazônicos são igualitários, não possuem riquezas. E então, quando observamos o Uaupés, nos perguntamos: igualitários? Ao contrário: eles são radicalmente hierárquicos, são obcecados por hierarquia! Não têm riqueza? Vejam-se por exemplo os livros da Coleção Narradores Indígenas, ${ }^{2}$ em que os índios traduzem consistentemente por "riqueza" a palavra da língua barasana gaheuni ou sua variante em língua tukano, apehuni. Note-se que se trata de conceito equivalente ao de nekrets dos Kayapó e Xikrin (ver Lea, I986). Ora, os índios não têm a menor dúvida de que possuem riqueza! Então, Viveiros de Castro me parece correto quando afirma que as relações com o exterior devem ser incluídas como parte de nossas análises sociológicas. Não posso, entretanto, concordar com o fato de que canibalismo e predação - mesmo em nível muito metafórico - sejam o que há de mais operativo no Uaupés. Se lançamos os olhos para mitologia associada às trocas cerimoniais - os charter-myths, como diria Malinowski (I954) - há uma narrativa sobre canibalismo, em que a troca cerimonial falha. O mais importante charter-myth, no entanto, versa sobre as relações de afinidade entre um sogro e um genro. O sogro ameaça comer o genro, que argumenta: "não faça isso, eu vou trazer para você carne de animal". O que significa "vou trazer o meu próprio corpo, a carne da minha própria gente e oferecer cerimonialmente a você". E o sogro, que é um Peixe-Sucuri (fish-anaconda), isto é, o dono, mestre, ou "pai" dos peixes, diz: "se é assim, em troca vou oferecer a você peixe". O que está acontecendo aqui, portanto, é o inverso do canibalismo. É muito mais como um sacrifício. $O$ ancestral dos Barasana oferece animais que são parte de si mesmo, de seu corpo, de sua substância, para o Peixe-Sucuri, e este último, em troca, lhe oferece peixe. Apesar da dimensão sacrificial, essa é a lógica da 
troca-dom e não aquela do canibalismo. Isso é exatamente o que Marylin Strathern quer mostrar ao dizer que, quando uma pessoa na Nova Guiné dá sua irmã em casamento, ela está dando uma parte de si. Essa mulher é um dom, ela permanece sendo parte de seu irmão, de seu pai, daqueles que a ofereceram.

C.L. Trata-se, então, de um cenário amazônico em que há objetos, riquezas e trocas do tipo dom?

S.H-J. Do meu ponto de vista, parecem equivocadas tanto as generalizações sobre as sociedades amazônicas que as retratam como sociedades igualitárias, endógamas, cognáticas, amistosas, não violentas, quanto as que as caracterizam pelo canibalismo e pela predação. Mas não acho que isso seja simplesmente uma questão de dizer "minha etnografia não bate com a sua etnografia". Esse tipo de observação não é interessante, porque é evidente que existe enorme variedade etnográfica na Amazônia. Uma das coisas que meu trabalho mostra é precisamente essa variedade. E ela não diz respeito somente aos Tukano orientais, é verdadeira também para os povos de língua jê e os Xinguano. Mas, sobretudo, tenho a impressão de que Lévi-Strauss estava certo quando disse que não analisaria a mitologia dos Tukano orientais por se tratar de remanescentes de uma civilização amazônica.

C.G. De fato, Lévi-Strauss mais de uma vez aventou a hipótese de que a situação contemporânea dos povos ameríndios era resultado de um processo de fragmentação de civilizações mais antigas e complexas que talvez tenha ocorrido em épocas pré-colombianas.

S.H-J. Vou dizer como vejo o estado da etnografia amazônica atualmente. Imagine que você está estudando as ilhas britânicas depois de uma guerra nuclear, depois de uma bomba cair em Londres. Então você vai fazer etnografia na Escócia, no País de Gales, na Cornualha, ou seja, em lugares vazios, selvagens e periféricos. Você certamente não terá uma ideia muito clara do que foi a civilização britânica, estudando pessoas das terras altas da Escócia e do País de Gales. Acho que as generalizações sobre a Amazônia não levam em consideração a história. Pensemos na cerâmica marajoara e de Santarém. É óbvio que aquela cerâmica é produto de uma divisão especializada do trabalho, de sociedades estratificadas e que foram capazes de manter diferenciações sofisticadas. Eu suspeito - não tenho qualquer prova, mas tenho uma intuição - de que algumas características das sociedades do noroeste amazônico podem fazer-nos vislumbrar o que eram essas outras sociedades amazônicas no passado. Esses grandes temas sempre estiveram subjacentes ao meu trabalho, por exemplo, quando escrevi sobre sociedades de casa (Hugh-Jones \& Carsten, I995) e sobre cultura material. Se pretendemos entender a Amazônia como fenômeno histórico complexo, temos que levar essas questões a sério. 
Por isso estou muito interessado em buscar as diferenças e similaridades entre os casos dos Jê do Brasil central e dos Tukano orientais do noroeste amazônico, porque nenhum dos dois se encaixa no modelo-padrão amazônico. Do mesmo modo que o alto Xingu não se encaixa. Em última análise, uma vasta área, que inclui um grande número de populações indígenas, não se deixa enquadrar pela visão dominante, por assim dizer.

C.L. Seria útil então trazer o conceito de civilização para os estudos sobre a Amazônia?

S.H-J. Sim e por várias razões. Primeiro porque funcionaria como um corretivo para algumas distorções. Não apenas em alguns círculos antropológicos, mas principalmente no senso comum, a imagem da Amazônia sempre foi tributária de duas vertentes: de um lado, a vertente rousseauniana; de outro, a vertente hobbesiana. O trabalho de Napoleon Chagnon (I968, I992) sobre os Yanomami, por exemplo, está no lado hobbesiano. Os grupos amazônicos seriam guerreiros selvagens, temerários e perigosos. Mesmo pelo lado rousseuniano, entretanto, em que se situa, por exemplo, o trabalho de Joanna Overing, que os retrata pacíficos e gentis, eles ainda são vistos como povos muito pouco sofisticados: não têm riqueza, não têm hierarquia, não têm troca-dom. São sociedades simples. Essas imagens dos índios amazônicos como sociedades simples, puras, não contaminadas tornam oportuna a noção de civilização. Se falamos em civilização inca ou civilização asteca, podemos perfeitamente falar em civilização amazônica.

C.L. Isso é mais ou menos o que Carlos Fausto, Michael Heckenberger e outros sugerem, em coautoria, sobre o alto Xingu (Heckenberger et al., 2008).

S.H-J. Exatamente. Gosto muito desse artigo e acho muito interessante a combinação de arqueologia e antropologia que vem caracterizando o trabalho deles. No noroeste amazônico encontramos um amplo conjunto de povos - estamos falando a respeito dos Tukano orientais, dos Baniwa, de outros Aruak como os Yukuna, Matapi e até os Witoto e os Tikuna -, que se diferenciam muito do modelo-padrão amazônico. São povos que, de um modo ou de outro, possuem linhagens, tradições intelectuais e sacerdotais elaboradas, formulações explícitas de hierarquia, arquitetura complexa. Esta é uma Amazônia bem diferente daquela que serviu de inspiração ao modelo de que vimos falando.

C.G. Como você entende essa diferença entre o modelo minimalista e esse modelo mais complexo do noroeste amazônico, do Brasil central e alto Xingu? Ela se deve a percursos históricos distintos ou se trata de diferenças "culturais", quero dizer, formas diferentes de ser indígena? A história dos grupos que estavam sofrendo mais diretamente o impacto da conquista pode explicar essa diferença? Ou ela se explica por outros fatores, digamos, internos? 
S.H-J. Há dois processos em questão. Um deles é histórico. Creio que se alguém fosse ao alto ou ao médio Rio Negro em I 300 , veria um sistema social muito mais complexo do que o de hoje. Os Tukano, os Baré, os Baniwa, e também aqueles grupos que desapareceram, como os Manao, passaram por um processo de desgaste nas mãos dos colonizadores, assim como os grupos tupi e os Carib das Guianas. Acho que é uma ilusão imaginar que os Piaroa ou os Trio de hoje são os mesmos de 500 anos atrás. Estou certo de que eles possuíam sistemas comerciais mais complicados, e as pesquisas históricas e etno-históricas vêm comprovando isso. Eu diria que os Piaroa tendiam a ser mais como os Tukano, com o complexo do Jurupari, flautas etc. Se lemos os primeiros trabalhos de Joanna Overing (1972, I975) fica evidente que há até mesmo como falar em hierarquia. De modo que a história é um fator de influência considerável. Por outro lado, creio que podemos, sim, falar em estilos radicalmente diferentes, que operam de maneira independente da história. Não importam as razões, sejam elas ecológicas ou resultantes de uma combinação mais complexa de fatores, há alguma coisa diferente sobre os Xinguano, os Jê e os Tukano em relação a povos como os Araweté, por exemplo. Vejamos os Tupinambá antigos: é perfeitamente possível manter grandes populações e grandes aldeias sem ter o tipo de organização social do noroeste da Amazônia. Você não precisa de hierarquia e de um sistema de especialização do trabalho para sustentar grandes populações. Há evidências históricas e arqueológicas de grandes aldeias dos Jê há 200 anos, mas elas certamente não estavam organizadas da mesma forma que as aldeias dos Tukano. E não há muitos indícios de grandes aldeias tukano no passado, embora haja alguns. Os próprios Tukano ainda hoje falam da existência pretérita de conjuntos nucleados unindo várias malocas, mas não se sabe ao certo.

C.G. Há ainda todo um programa de pesquisa em aberto.

S.H-J. Essas questões são relevantes para o nosso entendimento da história cultural da Amazônia, e acho um tanto irônico que, no momento em que nos tornamos capazes de respondê-las, elas fiquem fora de moda para o resto da antropologia. Isso é lamentável. Se observarmos a história da pesquisa etnográfica na Melanésia, veremos que foi precisamente nos últimos 20 ou 30 anos que se começou a reunir uma grande massa de conhecimento. Refiro-me não só ao trabalho de Marylin Strathern (I988), iniciado com The gender of the gift. Há uma série de estudos comparativos que buscam sintetizar a etnografia melanésia, o que a meu ver é muito interessante, porque tais trabalhos nos ajudam a refletir sobre o própria natureza da comparação. Infelizmente, o que aconteceu em relação à Amazônia foi que o debate antropológico se deslocou precisamente no momento em que poderíamos dizer que a Amazônia está hoje longe de ser o continente menos conhecido, como foi dito nos anos I960. Hoje estamos numa posição de fazer sínteses, mas a antropologia, de um modo geral, não tem interesse nos índios amazônicos. 
C.L. Aproveitando o gancho, vamos passar a outro nível de comparação. No artigo "The gender of some Amazonian gifts" (Hugh-Jones, 200I) você desenvolve um experimento que denominou "troca conceitual inter-regional". Ali você tenta aplicar na análise dos rituais secretos masculinos no noroeste amazônico a abordagem relacional de gênero desenvolvida por Marylin Strathern no livro que acabamos de mencionar. Esse artigo foi escrito no contexto de um projeto de comparação inter-regional que envolvia pesquisadores da Amazônia e da Melanésia. Como você avalia os resultados desse esforço, no seu próprio trabalho e em geral?

S.H-J. Vou começar minha resposta relatando uma experiência que tive como estudante de graduação. Certa vez, perguntei a Esther Goody - ex-esposa de Jack Goody - por que deveríamos estudar feitiçaria, mas não xamanismo, já que me parecia que feitiçaria e xamanismo eram na verdade versões da mesma coisa. A resposta dela foi: "Stephen, feitiçaria é uma instituição social, xamanismo é algo que aparece somente em áreas etnográficas específicas, como a Amazônia". Essa distinção feita por Esther Goody ficou gravada em minha mente. Penso que parte do problema da antropologia amazônica é que muitos antropólogos não americanistas sempre a trataram como Esther Goody, isto é, como uma província exótica e atrasada, e não como parte da corrente principal da antropologia. Por outro lado, acho também que, com algumas exceções, os próprios antropólogos que estudam os povos indígenas da Amazônia também a tratam dessa forma ou, pelo menos, insistem muito nas especificidades incontornáveis do mundo ameríndio. Parece simpático, mas com isso acabam cavando a própria sepultura, por assim dizer. Eis uma das razões pelas quais eu fico ressabiado quando autores como Philippe Descola, Eduardo Viveiros de Castro e Joanna Overing afirmam categoricamente que não há dádiva na Amazônia, ou que as sociedades amazônicas são sociedades de brideservice e não de bridewealth. Esse é um tipo de categorização tipológica reducionista e que pode levar a antropologia da Amazônia a um isolamento, a uma espécie de gueto. Talvez essa minha tendência se deva ao fato de eu ter sido aluno de Leach e de ter sido exposto à realidade do noroeste amazônico.

C.L. Uma curiosidade: por que, precisamente, você foi fazer os estudos de pós-graduação com Leach e não com Peter Rivière, que era um especialista da área?

S.H-J. Na verdade, quando me formei, eu tentei ir para Oxford a fim de estudar com Peter Rivière, justamente porque meu objetivo era me tornar um especialista em Amazônia. Mas, felizmente, quando fui entrevistado em Oxford por Godfrey Lienhardt e por um historiador da América Latina chamado Raymond Carr, eles me disseram: "Nós não gostamos do seu projeto de estudar os índios da Amazônia. Estaríamos mais interessados se você quisesse estudar os povos das terras altas sul-americanas. Os índios amazônicos não são interessantes. 
Trata-se de uma digressão romântica e irrelevante". E eu então retruquei a Lienhardt, que fizera suas pesquisas de campo com os Dinka do Sudão: "Diga-me qual é a relevância dos Dinka para a política contemporânea séria?" Claro que, depois desse diálogo, eu não fui selecionado. Mas o episódio ilustra perfeitamente essa visão dos índios amazônicos a que há pouco me referi.

\section{C.L. Você disse "felizmente"?}

S.H-J. De certa forma foi um golpe de sorte ter a candidatura recusada em Oxford. Não por causa de Rivière, que certamente teria sido um ótimo orientador. Porém, a orientação de Edmund Leach foi muito importante na minha trajetória. Quando eu e Christine estávamos escrevendo nossas teses, Leach nos recomendava a todo momento: "Eu não me importo com o que dizem os especialistas em Amazônia, isto é bobagem, vocês têm é que ser convincentes". Nós precisávamos convencê-lo o tempo todo. E, além disso, tivemos a oportunidade de manter contato com Peter Rivière e com outros colegas amazonistas. Ganhamos dos dois lados.

C.G. Você tem insistido na vinculação da etnologia indígena amazonista ao corpo mais geral dos debates antropológicos. E hoje parece que, de fato, o chamado "americanismo das terras baixas" não se encontra tão isolado e começa a chamar a atenção da antropologia geral. As tentativas de comparação com a Melanésia, voltando à pergunta, não seriam um exemplo disso?

S.H-J. Se olharmos para a história da antropologia, veremos que as teorias têm origem regional. A África nos dá o estrutural-funcionalismo, as teorias das linhagens, a teoria da descendência, além de todo um vocabulário: feitiçaria, bridewealth etc. Os melanésios nos deram todo o vocabulário da troca e da reciprocidade que tem sido útil para repensar a própria teoria da descendência. Quanto à Amazônia, temos, ou até bem recentemente tivemos apenas Lévi-Strauss, forjando uma linguagem estruturalista própria a partir do universo mitológico indígena. Agora temos também Viveiros de Castro e Descola, por exemplo. Mas tanto por razões teóricas quanto, talvez, pela especificidade do caso do noroeste amazônico, sempre foi claro para mim que a antropologia amazônica tinha que representar uma contribuição para a teoria antropológica como um todo e também estar sempre aberta à teoria antropológica geral. E foi isso o que tentei fazer no experimento sobre o gênero da dádiva na Amazônia. Embora eu não tenha explicitado isso no texto, ali eu estava me dirigindo a Viveiros de Castro, Descola e Joanna Overing quando afirmam não haver dádiva na Amazônia. Tentei mostrar que, ao contrário, podemos pensar certos fatos etnográficos do noroeste amazônico a partir da teoria do dom. Nesse sentido, a Melanésia coloca questões importantes para nós: o que faz com que a região seja de alguma forma tão parecida com a Amazônia e, ainda assim, tão curiosamente diferente? É muito interessante observar que a 
mitologia do noroeste amazônico associada ao complexo do Jurupari é quase idêntica à mitologia das terras altas da Nova Guiné publicada por autores como Gillian Gillison (I993). Ou tomamos isso como evidência da reminiscência de um pensamento religioso paleolítico - pois sabemos que, se houve difusão, ela se deu há muito tempo -, ou imaginamos que as mesmas ideias brotaram espontaneamente nos dois lugares, como sugere Lévi-Strauss quando afirma que num nível profundo todos estão pensando do mesmo modo. Essa questão em si, para mim, já é muito interessante.

C.G. E essas questões motivaram outras reflexões que você empreendeu, como, por exemplo, a discussão sobre os objetos?

S.H-J. Embora eu não tivesse chegado ainda nesse estágio de minha reflexão quando comecei a trabalhar com o tema, já me incomodava a ideia generalizada de que a Amazônia era um universo pobre em termos de objetos, de que não há representação artística de figuras humanas, ao contrário de certas partes da Melanésia e da África em que há gravura e escultura. Assim como a ideia de que, na Amazônia, não há domesticação de animais nem bridewealth. Minha experiência com os índios do noroeste amazônico não corroborava essa visão. Não se trata de um universo pobre de objetos; na verdade as pessoas se esmeram na criação de objetos muito delicados e há evidências de que no passado faziam objetos ainda mais sofisticados. Por razões etnográficas e também teóricas, portanto, estive interessado em dialogar com Marylin Strathern.

C.L. Aqui temos um ponto interessante, porque o trabalho de Strathern não enfoca simplesmente o problema da dádiva. Como você bem disse, esse é o tema clássico da etnografia melanésia. A diferença do trabalho de Strathern é que ela interpôs a questão de gênero na problemática da dádiva. Essa não seria mais uma razão para aproximar a Melanésia do noroeste amazônico, onde, sabemos, a questão de gênero é sociológica e simbolicamente relevante? S.H-J. Certamente. No artigo que mencionamos há pouco, publicado na coletânea Gender in Amazonia and Melanesia, Philippe Descola também afirma que a distinção de gênero não é muito importante na Amazônia, porque ela é eclipsada ou abrangida por distinções mais globais como afim/consanguíneo, estrangeiro/local etc. Ora, novamente, essa distinção talvez não seja importante em outras partes da Amazônia, mas ninguém pode nem sequer conceber que ela não seja importante no noroeste amazônico. A experiência etnográfica cotidiana de viver em uma maloca que possui uma porta dos homens e uma porta das mulheres não deixa nenhuma dúvida quanto ao caráter operativo da distinção de gênero ali. Fato é que os Tukano orientais explicitam certas operações estruturais que outros povos podem não explicitar. Quando eu estava escrevendo meu livro, havia duas coisas de que eu desconfiava fortemente, mas não tinha coragem de afirmar com todas as letras. Uma delas era que a 
personagem mítica Romi Kumu, uma mulher-xamã, era a mesma pessoa que Sucuri-Maniva ou Jurupari (manioc stick anaconda). Em se tratando, porém, de sociedade tão fortemente marcada pelo gênero, parecia um absurdo dizer que Jurupari, a quintessência do masculino, era a mesma pessoa que Romi Kumu, a quintessência do feminino. Eu já havia percebido que Romi Kumu era de certa forma uma figura andrógina, o próprio fato de ela ser chamada de mulher-xamã era um forte indicativo dessa possibilidade, já que xamãs são tradicionalmente do sexo masculino. Os próprios índios sugeriam, de vários modos, que se tratava de uma personagem andrógina. Então, um dia, em I979, quando eu conversava com Pasico, o kumu que me ensinou tudo o que sei e que se tornou amigo, ele me disse: "Stephen, você sabia que Romi Kumu é um homem?" E eu disse "O quê? Eu sempre pensei isso, mas nunca tive coragem de dizer". E ele respondeu: "Eu tenho coragem de dizer".

Essa experiência levou-me à compreensão de que era uma ingenuidade achar que homens eram homens e mulheres eram mulheres. E, então, eu li Marylin Strathern que afirmava poderem, na teoria melanésia do gênero, homens e mulheres ser do sexo masculino ou feminino. Esse tipo de pensamento se adaptava muito bem a meu próprio material, e foi por isso, também, que resolvi escrever aquele artigo. Há muito tempo eu me interessava pela etnografia melanésia e pelas possibilidades de comparação com o noroeste amazônico, principalmente no que dizia respeito ao complexo do Jurupari. O interesse pela Melanésia precipitou de alguma forma o desenvolvimento de minha reflexão sobre gênero. Mas, por outro lado, eu também havia sido formado na teoria da troca e sempre desconfiei de que havia algo que não se encaixava bem na teoria amazônica dominante.

C.L. Você encarou dois grandes desafios: digerir Mitológicas, de Lévi-Strauss, e, anos depois, o livro de Marylin Strathern, que não é fácil.

S.H-J. Eu já havia tentado ler The gender of the gift várias vezes e simplesmente não havia conseguido compreender uma só palavra. Então, quando fui chamado a participar da conferência que deu origem à coletânea, decidi que dessa vez iria ler com afinco. Levei dois meses para ler o livro e no final percebi o que ela estava tentando fazer. Entendi o modo como Marylin Strathern compara as partes leste e oeste das terras altas da Nova Guiné - a primeira com seus cultos secretos masculinos, e a segunda com suas trocas cerimoniais, e como as duas formas são transformações uma da outra. Eu estava trabalhando com uma sociedade que possui tanto rituais secretos masculinos quanto trocas cerimoniais. Então escrevi o artigo como um tributo a Marylin Strathern, como uma forma de dizer que valeu a pena passar todo um verão lendo o seu livro. Foi uma verdadeira revelação. Escrevi outros artigos, especialmente "Brideservice and the absent gift" (Hugh-Jones, 2013), em que confronto muitos de meus colegas amazonistas pelo fato de eles pensarem de modo tipológico e adota- 
rem o axioma de que os índios da Amazônia são sociedades de brideservice, como sugeriu Eduardo Viveiros de Castro (I993) em seus primeiros trabalhos sobre o dravidianato amazônico. É exatamente o que Joanna Overing também faz. Há vários erros nessa premissa. Um deles é imaginar que todos os índios da Amazônia são iguais; o segundo é o de pensar que se trata de um mundo muito pobre, em que, se você é uma coisa, não pode ser outra. Esse tipo de classificação não pode dar conta da enorme variação nos padrões de casamento existentes, por exemplo, no noroeste amazônico. O tipo mais trivial e politicamente menos interessante de casamento é o casamento relativamente endógamo de primos cruzados. O casamento politicamente mais interessante é o casamento distante, entre grupos que ocupam posições altas na hierarquia regional. Se você é um homem poderoso, tentará fazer uma aliança política estratégica com alguém que está distante. Portanto, dependendo de quem você seja e de quais sejam suas circunstâncias políticas, você realiza um casamento exógamo, relativamente exógamo ou relativamente endógamo. Só os homens de baixo status cumprirão o serviço da noiva no noroeste amazônico. Só um homem que está desesperado por uma mulher. Nenhum homem de mínimo valor cogitaria fazer serviço da noiva. Portanto, descrever os Tukano orientais como sociedades de serviço da noiva é uma bobagem completa.

C.G. A propósito, você acha que o fato de ter sido orientado por Leach potencializou sua capacidade de perceber essa flutuação dinâmica no nível interno de uma sociedade? Ou seja, há diferentes regimes que coexistem e se alternam. Godelier, evocado por Descola no artigo que comentamos, demonstra algo equivalente entre os Baruya da terras altas da Nova Guiné, que conjugam dois regimes de troca. S.H-J. Sim, ao escrever esses artigos, eu tinha em mente a ideia de que é perfeitamente possível haver tendências contraditórias dentro da mesma sociedade ou dentro do mesmo sistema social, tal como a variação gumsa/gumlao tão bem descrita por Leach em Political systems of Highland Burma. Estou ciente de que não fiz muito trabalho comparativo, mas há várias possibilidades. Tome-se, por exemplo, Marriage among the Trio, de Peter Rivière. É evidente que, embora o ideal de casamento guianês seja endogâmico, na verdade há homens de prestígio realizando casamentos exógamos. E o fato de haver sobreposição dos termos para cunhado e parceiro comercial deixa muito claro que temos os dois tipos de processo funcionando ao mesmo tempo. A percepção crucial que levou Eduardo Viveiros de Castro ao desenvolvimento de suas reflexões tanto sobre a alteridade potencial quanto sobre o perspectivismo é a de que aquilo que as gerações anteriores de etnólogos viam em termos de oposições binárias ou diametrais precisava, de fato, ser disposto em escala de proximidade e distância, isto é, gradualmente. Havia, portanto, uma duplicidade de códigos em torno do mesmo fenômeno do parentesco: uma chave diametral e outra chave concêntrica. E elas podem ser acionadas alternadamente. 
C.G. O próprio Lévi-Strauss (I956), décadas atrás, havia percebido a alternância entre dualismo diametral, dualismo concêntrico e ternarismo nas sociedades dos Jê e dos Bororo, e evocava uma analogia com a Melanésia, justamente em termos de diferenças de gênero!

S.H-J. As estruturas são dinâmicas e, de certa forma, manipuláveis e abertas à história. Em algum lugar, Eduardo Viveiros de Castro escreveu uma nota de rodapé provocativa afirmando que as unidades sociais concretas, on the ground, são produto da história. Mas o curioso é que não há muita história em suas reflexões. Há muita estrutura e pouca história. Não que isso seja um defeito, mas é preciso analisar os fenômenos em vários níveis.

C.G. Por falar em dinamismo, você tem sido sempre um tipo de intelectual dinâmico, que nunca se acomoda com uma teoria ou um modelo. Em suas pesquisas, há sempre a possibilidade de novas abordagens. Além do diálogo com Marilyn Strathern, temos, por exemplo, sua aplicação da noção de casa, de Lévi-Strauss, no contexto do Uaupés. Você ficou satisfeito com os resultados dessa aplicação, que aparecem no livro que editou com Janet Carsten e também em um artigo publicado em uma edição especial de L'Homme, em que a questão de gênero, da ambivalência e da androginia também estão presentes? (ver Hugh-Jones, I993, I995).

S.H-J. Primeiramente, deixe-me esclarecer que meu modo de trabalhar se deve a vários fatores. De um lado, houve as circunstâncias familiares, como o fato de Christine ter seguido a carreira de médica. De outro lado, minha preguiça em aprender uma nova língua indígena, além da barasana, para poder fazer trabalho de campo com outro grupo indígena, em outra região. E, por fim, o fato de os índios do Uaupés, a mim, sempre terem parecido incrivelmente interessantes. Eles são muito instigantes, com sua sofisticação artística e intelectual, constituem de fato uma civilização. Considero-me muito sortudo por ter trabalhado com essa sociedade tão rica em tantos aspectos. Tê-los como base de minha antropologia foi o que me permitiu explorar territórios de pesquisa tão diversos. Venho me debruçando sobre temas como arquitetura, noção de casa, troca, contato com os brancos, etnobiologia. Tenho um manuscrito praticamente completo sobre cobras. Quando realizo um projeto, costumo colocar um ponto final. Escrevo e depois me volto para outro tema. Estou sempre em movimento. Eu e Christine tínhamos um projeto de escrever sobre as relações com o mundo exterior. Meus trabalhos sobre o escambo e sobre os mitos a respeito dos brancos (Hugh-Jones, I 992 e I 988 , respectivamente) são desenvolvimentos desse antigo projeto, no qual Christine não se engajou porque decidiu estudar medicina. Costumo também atender a convites de colegas. Caroline Humphrey teve a ideia de fazer um livro sobre o escambo (Humphrey \& Hugh-Jones, I992); eu nunca tinha pensado nesse assunto, mas resolvi tentar. Sempre tive interesse em arquitetura. Eu e Christine já tínha- 
mos também escrito muito sobre os significados e o simbolismo arquitetônico. Cheguei a contribuir com um verbete numa enciclopédia sobre o tema (Hugh-Jones, I 997). Há muito tempo eu me interesso por arquitetura. Janet Carsten chegou ao tema das sociedades de casa a partir da perspectiva das sociedades cognáticas. Eu cheguei a partir de meu interesse pela arte e pela arquitetura. Na verdade, foi um casamento intelectual muito feliz. Minha contribuição no projeto do livro foi realmente trazer a arquitetura de volta às sociedades de casa. Quando escrevemos a introdução, estávamos determinados a afirmar que o problema da teoria de sociedades de casa de Lévi-Strauss era o fato de ele se ter esquecido do aspecto arquitetônico e material. Na verdade, em La voie des masques (Lévi-Strauss, I979), que é um dos trabalhos em que ele elabora sua tese, há fotografias maravilhosas de casas dos Tsimshian. Era óbvio que, como uma sociedade de casas, eles estavam fazendo casas muito elaboradas; mesmo assim, Lévi-Strauss não desenvolve esse ponto.

C.L. Além da questão de gênero, os textos sobre as sociedades de casa colocavam um problema para a noção de descendência no contexto do Uaupés. Os grupos do noroeste amazônico sempre foram descritos como patrilineares. Seus artigos, porém, indicavam uma tensão interna que os aproximava das sociedades cognáticas. Nesse aspecto, o Uaupés se aproximava de muitas outras sociedades amazônicas, afinal de contas?

S.H-J. Eu acabei percebendo que era muito fácil descrever os índios do Uaupés como patrilineares. Era fácil porque parecia que estávamos falando a respeito da África. Não quero criticar meus colegas, mas, por exemplo, Kaj Arhem, que escreveu sobre os Makuna, grupo quase idêntico aos Barasana, os descreve como um típico sistema segmentar de aliança. Creio que não se trata de fato de uma sociedade segmentar. O famoso modelo dendrítico (ou por ramificação) da linhagem africana, tal como descreveu Evans-Pritchard, não se aplica aos Tukano. Na minha opinião, a essência da cosmologia do Uaupés é uma lógica fractal, em que a casa é o corpo e é o Universo, ao mesmo tempo. E pode-se passar de uma escala a outra. Todo o xamanismo depende disso; dessa possibilidade de transitar em diferentes escalas, do micro ao macrocosmo. Tive oportunidade de ouvir os índios comentarem que era exatamente assim que eles entendiam. Então, embora eu os tenha descrito inicialmente como patrilineares, em larga medida para dizer que eles não eram cognáticos (e, naquela altura, dizer que eles não eram cognáticos implicava dizer que eram lineares), eu sempre soube que eles eram patrilineares de um modo muito específico. Não se trata de um idioma de substância; o que se transmite ali são nomes, objetos, línguas. É uma transmissão espiritual, imaterial. Portanto, quando comecei a ler o trabalho de Lévi-Strauss sobre as sociedades de casa, percebi imediatamente que havia ali uma contradição, uma inconsistência. Ele descreve bem os sistemas cognáticos, as sociedades de casa clássicas, na Ásia. Quando, entretanto, vai falar sobre as 
casas nobres da Europa e sobre a costa noroeste dos Estados Unidos, entramos num território de quase linhagem, pelas razões que Lévi-Strauss aponta, isto é, porque elas combinam aliança e descendência. Achei muito interessante porque me parece que os clãs e as linhagens do Uaupés são de fato casas no sentido de Lévi-Strauss. Existem grupos cujas identidade e persona são baseadas na transmissão de propriedade. Nesse caso, porém, a transmissão é patrilinear, ela segue uma linha. Não consigo encontrar exemplos em que a linha siga uma esposa vinda de outro grupo. É bem consistente, nesse sentido.

C.G. Seria possível relacionar de algum modo essa análise ancorada na noção de casa com o experimento que você fez de investigar os rituais por meio do modelo de Marilyn Strathern em The gender of the gift?

S.H-J. Sim, eu poderia estabelecer essa relação em dois sentidos diversos. Primeiro, temos a característica peculiar do sistema social do Uaupés, que é o fato de os clãs e linhagens serem casas, no sentido lévi-straussiano do termo. Em outras palavras, isso significa que a identidade dos grupos deriva da manutenção de um corpo de propriedade material e imaterial. Nesse sentido, se eu fosse forçado a tipificar, diria que se trata de sociedades de preço da noiva. Não diria isso de bom grado, porque acho que dizer isso é uma bobagem. Mas eles estariam com certeza do lado das sociedades de preço da noiva. Em outras palavras, eles certamente veem a possibilidade de que objetos possam ser pessoas e possam substituir pessoas. Trata-se de sociedades orientadas para várias formas de troca, incluindo a troca de riqueza. Portanto, o fato de que essas casas são grupos detentores de riqueza faz com que elas se encaixem no modelo.

O outro sentido no qual percebo a conexão que você menciona em sua pergunta é o seguinte. Esses grupos ou casas imaginam sua continuidade a partir de uma inflexão de gênero. Sua continuidade no tempo se dá pela transmissão da propriedade, que inclui língua, sêmen, ossos, espírito, narrativas, objetos sagrados, flautas jurupari etc., que são elementos masculinos. Todo esse idioma masculino possui uma contrapartida feminina, que lhe é complementar. Aqui, sim, poderíamos falar em termos de substância; por exemplo, os ossos (do gênero masculino) são envolvidos pela carne e o sangue (que são do gênero feminino). Nesse sentido, eu tenderia a concordar com Kaj Arhem, embora eu não goste da caracterização do sistema do Uaupés como um sistema segmentar de aliança. Prefiro caracterizá-lo como sociedade de casas envolvidas em um sistema de aliança, de forma semelhante ao que Susan McKinnon (I995) descreveu para as Ilhas Tanimbar na Indonésia. E, nesse caso, tratava-se de sistemas de aliança assimétrica. Enfim, isso nos leva, em última análise, à grande tensão na teoria do parentesco de Lévi-Strauss. Se tomarmos a teoria clássica da aliança, veremos que ela depende simultaneamente da descendência e da aliança. Precisamos dos grupos de descendência, pois são eles que 
estabelecem e definem a aliança; e precisamos da aliança para reproduzir os grupos ao longo do tempo. Parodiando Firth, para encurtar: na teoria da descendência o casamento serve para reproduzir os grupos de descendência; e na teoria da aliança, os grupos de descendência servem para garantir o casamento. Pois bem, se pensarmos em termos de uma tipologia da Amazônia, a maioria dos grupos poderia encaixar-se do outro lado da teoria da aliança, como mostrou Viveiros de Castro. Não o lado dos grupos de descendência e do chamado método das classes, mas o lado do método da relações, em que não há linhagens ou descendência. Parece-me, no entanto, que o que vemos nas sociedades do Uaupés é, de fato, a aliança no sentido mais clássico. Em outras palavras, e seguindo o modelo quase evolucionista de Lévi-Strauss, começamos a sair do terreno de sistemas elementares de aliança, para sistemas mais complexos, ponto em que as sociedades do Uaupés parecem assemelhar-se às melanésias. Eduardo Viveiros de Castro referiu afinidade sem aliança; Lévi-Strauss, troca sem bridewealth. A troca cerimonial melanésia tinha ido além desse tipo de substrato matrimonial. Parece-me que é isso, também, de certa forma, o que ocorre no noroeste amazônico. Aí existe uma diferença entre aliança por meio da troca de irmãs e aliança por meio da troca de bens cerimoniais. Os índios do Uaupés se referem à troca de bens cerimoniais como aliança ancestral. E, o que é muito interessante, eles agora estão usando essa expressão com relação aos antropólogos que trabalham com eles em projetos, como eu mesmo e as pessoas da Fundação Gaia. Eles nos chamam pelo termo que significa parceiro ou aliado cerimonial. Enfim, aqui nós estamos au delà das estruturas elementares do parentesco, isto é, já começamos a entrever uma situação em que pode haver troca não necessariamente ligada à aliança matrimonial. Então, eu penso que, sim, é possível fazer uma articulação entre esses artigos que você mencionou, embora eu nunca tenha colocado isso no papel.

C.G. Podemos encontrar trocas cerimoniais também em outros lugares. Entre os Waiana das Guianas, por exemplo, há um tipo de parceria cerimonial que não tem nada a ver com casamento. É apenas troca cerimonial.

S.H-J. Sem casamento, exatamente. Viveiros de Castro está absolutamente certo quando afirma que a afinidade pura é a afinidade sem casamento. $\mathrm{Na}$ minha opinião, porém, a afinidade pura não é necessariamente afinidade canibalística. Pode haver afinidade sem casamento de um modo relativamente pacífico, recíproco. Isso é de fato a base dos grandes sistemas sociais que encontramos no Xingu e no noroeste da Amazônia.

C.L. Estávamos falando sobre seu dinamismo; você é um antropólogo do tipo inquieto, que está sempre em busca de novas perspectivas. Gostaria que você falasse um pouco a respeito de suas reflexões acerca da questão do contato com os brancos. Na monografia sobre os Barasana (Hugh-Jones, I979) você 
adotou uma perspectiva tradicionalista. Uma década depois, publicou o artigo "The gun and the bow" (Hugh-Jones, I988), no qual você explorou a visão dos índios do Uaupés sobre os brancos. Mais tarde, em I992, analisou a relação entre índios e brancos com foco no tema dos objetos. O que mudou? Os Barasana ou sua própria perspectiva?

S.H-J. Para responder a essa pergunta, tenho que voltar ao meu passado hippie. Embora eu ame meus pais e tenha sido influenciado de diversas maneiras por eles, toda a minha vida tem sido de certa forma estruturada numa antítese dialética a eles. Como eu já disse, meu pai era meio explorador como eu, mas ele queria que eu me tornasse médico. Foi a isso que reagi (ver Lasmar \& Gordon, 20I4). Christine e eu chegamos ao Pirá-Paraná ao mesmo tempo que os missionários, e uma das coisas que logo notamos foi que muitos dos jovens, principalmente os homens, estavam ávidos para adotar o modo de vida dos brancos. Queriam se vestir como os brancos, falar somente espanhol, ir à missa. Havíamos ido até lá para procurar índios verdadeiros e, no momento em que os descobrimos, tudo o que eles queriam era deixar de ser índios verdadeiros. Então, evitávamos a companhia dos jovens, embora fôssemos jovens. O problema era que os mais velhos não nos levavam a sério. Hoje em dia, quando eles me contam certas coisas e eu pergunto "Por que você não me disse isto antes?", eles respondem: "você ainda era muito jovem, não podíamos te contar essas coisas". Naquela época ainda nem tínhamos tido filhos, não éramos considerados plenamente adultos. De todo modo, parte da nossa estratégia era evitar ter contato com os mais jovens, especialmente os homens jovens, a fim de ter acesso a elementos mais tradicionais da vida dos Barasana. Eu me sentia culpado - como antropólogo, porque deveria pesquisar tudo; e no plano pessoal, porque tinha consciência de que, se eu fosse um deles estaria agindo do mesmo modo. O que eu estava fazendo? Procurando conhecer outras sociedades. O que eles estavam fazendo? A mesma coisa! Eles eram eu. E, mesmo assim, eu tinha algum ressentimento romântico, pelo fato de eles estarem dando as costas a sua própria tradição. E eu sempre me senti mal pelo fato de não conseguir ter afinidade com esses índios mais jovens.

C.L. Então, nesse primeiro momento, você e Christine abstraíram a dimensão da mudança e das relações com os brancos?

S.H-J. Nossos livros foram produtos de sua época. Se você estudava sociedades tribais, você não escrevia sobre os ruídos da aculturação, mudança, contato interétnico. Tínhamos, no entanto, consciência de que era necessário abordar a questão da relação com a sociedade moderna. Nosso segundo trabalho de campo foi explicitamente orientado para a relação entre os Barasana e os brancos. Fomos lá para fazer pesquisa sobre o tráfico de cocaína e estivemos também com os seringueiros em I968 e I97 I. Queríamos analisar a história dessas relações, e eles tinham muitas narrativas da interação com os patrões Baré. Nessa 
altura, porém, Christine começou a cursar medicina, e o livro que projetávamos sobre a relação com os brancos acabou nunca sendo publicado. Alguns de meus trabalhos dos anos I990 são o resultado dessas pesquisas. "Yesterday's luxuries, tomorrow's necessities" é sobre cocaína e mercadorias. Outra coisa que me intrigava era a categoria indígena "duturo". ${ }^{3}$ No livro que nunca escrevi, haveria um capítulo sobre a relação dos índios com os antropólogos.

Voltando à sua pergunta: a resposta é "sim" nos dois casos. Em parte, foram os próprios índios que mudaram e continuam a mudar. E nós também. Quando eu e Christine fizemos o segundo trabalho de campo, percebemos o quanto havíamos nos enganado em I 968 ao supor que, se abstraíssemos os missionários e os seringueiros que víamos diante de nós, poderíamos dizer que os índios sempre haviam sido tal como os víamos naquele momento. Foi apenas em I 979 que começamos a refletir sobre as implicações do fato de eles terem começado a usar machados de aço nos anos I930 e I940, sobre as implicações do fato de terem assimilado as mercadorias. Nesse sentido, é interessante comparar o caso do Uaupés com o caso Xikrin, pois os Barasana passaram pelo mesmo processo descrito no livro Economia selvagem (Gordon, 2006). Obviamente, as primeiras mercadorias que eles tiveram foram os machados e as facas, que eram itens raros de prestígio, e também armas e ferramentas, que os índios carregavam junto ao corpo como se fossem roupas. Todos esses, assim como as miçangas, eram categorizados como objetos sagrados, gaheuni, mas houve uma mudança semântica, e, agora, gaheuni designa qualquer coisa antiga. E, assim como entre os Xikrin, para os Barasana as mercadorias que aferiam prestígio outrora acabaram, com o passar do tempo, se tornando itens triviais. Hoje, os objetos ocidentais realmente "sagrados" são os computadores, portanto, eu diria que têm ocorrido mudanças importantes, e meu trabalho me fez entender que essas mudanças são muito mais profundas e contínuas do que inicialmente eu imaginava.

\section{C.L. Não seria o caso de retomar o projeto do livro?}

S.H-J. Outra razão pela qual eu não escrevi esse segundo livro está justamente no fato de que ele parecia um romance. As coisas iam mudando. Christine e eu pensávamos que iríamos estudar os seringueiros, e, quando chegamos lá, o grande tema era cocaína. Quando voltei na década de I980, a onda da cocaína já havia retrocedido e se falava em prospectar ouro. Agora isso acabou, e só se fala em projetos. O novo boom é o dos projetos de ONGs; todo mundo fala em projetos, em ONGs e em fazer filmes. Em suma, um livro sobre mudança não teria fim. Por outro lado, ocorre uma transformação que é, de fato, de muito mais longo prazo do que eu havia imaginado. Embora eu ainda adore ir a lugares bonitos com pessoas interessantes, tempo bom e muita natureza, deixei de ser um romântico, minha forma de pensar se alterou. Os jovens aos quais eu virei as costas no início da pesquisa - da geração que foi educada em missões, 
homens jovens que aprendiam a ler e escrever na escola missionária e rezavam aos domingos na missa - são os homens que hoje controlam a sociedade e que estão à frente da Asociación de Capitanes y Autoridades Tradicionales Indígenas del Rio Pirá-Paraná - Acaipi. Agora me dou muito bem com eles, tenho grande simpatia por suas posições e seus projetos políticos e culturais. E eles, por seu turno, têm muita afinidade comigo porque me conhecem desde que eram crianças e sabem que eu vi coisas que alguns deles nunca viram. Eles sabem o quanto eu aprendi ali, e por isso me respeitam. Fui iniciado por pessoas que já morreram, kumus famosos e muito conhecidos. Por tudo isso, temos hoje uma relação muito próxima.

\section{C.L. Novamente, a história é importante.}

S.H-J. Sim. E a minha antropologia mudou com ela. Eu agora não preciso mais passar tanto tempo em cima de um bloco de notas, tentando arrancar informações das pessoas. No início, eles tinham muitas suspeitas e não entendiam por que aqueles dois jovens estrangeiros ficavam fazendo perguntas altamente esotéricas sobre assuntos que não são normalmente discutidos no cotidiano deles. Ninguém discorre publicamente sobre seu conhecimento e certamente não fala sobre isso com estranhos. Era como extrair um dente... Mas hoje é uma relação inteiramente diferente. Estando aposentado, não sofro mais as pressões para publicar, divulgar meu trabalho. Posso fazer o que gosto e o que quero. Com tudo isso, o trabalho em cooperação com os índios é muito recompensador para mim. A atitude deles agora é a seguinte: "bem, se você não sabe isso, que diabos, você tem que saber; sente-se e eu vou te explicar" ou "venha aqui, venha cantar, venha cantar, você sabe pouco sobre nossos cantos, venha aprender a cantar melhor". Eles me chamam dizendo: "Você sabe dançar, vamos lá, por que você está sentado? Nós estamos dançando, você pode dançar também". Por outro lado, eles me perguntam coisas como: "o que é meio ambiente? Qual a diferença entre língua e linguagem?". E como falo razoavelmente bem o barasana, posso explicar esse tipo de coisa para eles. Com a experiência e o conhecimento acumulado, eu tenho segurança agora para fazer traduções e posso explicar às pessoas da Fundação Gaia, ${ }^{4}$ por exemplo, por que creio que elas estejam erradas quando fazem uso da noção de simbolismo para explicar o pensamento dos índios do Uaupés. Explico a eles que não é certo dizer que a casa é um símbolo do universo, pois, para os índios, sob certas circunstâncias, a casa é de fato o universo. Outro aspecto interessante: às vezes os índios me dão a incumbência de explicar às pessoas de fora certas coisas que elas querem saber. Por exemplo, certas pessoas chegam lá falando em lugares sagrados, mas continuam perguntando o que exatamente são lugares sagrados. E então os índios me pedem: "Stephen, você poderia explicar isso a ele?". De modo que a minha relação atual com eles é radicalmente diferente, é altamente cooperativa. Quando fui registrar seus cantos, meu 
interesse foi tanto em gravá-los quanto em ensinar-lhes a gravar. Eu deixei isso para o fim da minha vida e da minha carreira porque eles cantam em um língua tão complexa e metafórica, muito difícil de se produzir como fala. Essa língua sagrada, que eles chamam de keti oka, é a última coisa que eu tentaria aprender na minha carreira. Mas agora eu começo a compreender, e quanto mais eu entendo o que as palavras e os cantos significam, mais sou capaz de cooperar com eles no projeto de gravação desses cantos, de modo a ajustar minhas operações intelectuais com minhas operações práticas.

C.G. A propósito, gostaria de fazer uma pergunta mais geral. Agora que você está aposentado, fazendo o que gosta, e numa fase da vida em que se pode relacionar de modo mais livre com a antropologia, e olhando retrospectivamente, quais seriam, em sua opinião, as contribuições da etnologia dos índios da Amazônia para a antropologia britânica ou para a antropologia como um todo? Há espaço na antropologia britânica para se constituir uma etnologia sul-americana forte, tal como se constituiu uma etnologia africana ou a etnologia do sul da Ásia?

S.H-J. Eu acho que a antropologia não tem mais um projeto unificado. Quando comecei a estudar antropologia, na graduação, havia, de certa forma, um projeto unificado, em dois sentidos: primeiro, porque era possível, assim nos ensinavam, ler toda a boa literatura de antropologia da época. E isso era verdade, pois o número de monografias antropológicas no mundo era relativamente pequeno. Você podia se sair bem se se empenhasse bastante na graduação. Isso era sempre um pouco tendencioso, porque as leituras não incluíam necessariamente todos os livros escritos sobre os índios norte-americanos, por exemplo. O que os professores queriam dizer é que era possível ler todos os livros escritos por antropólogos britânicos, e assim obter satisfatório conhecimento etnológico. Nesse sentido, era realmente possível dominar e dialogar com o corpo de etnografias existente. Agora isso é totalmente inviável, absolutamente impossível. Há muito mais material sendo publicado, e a antropologia se tornou altamente especializada. Em todo caso, eu acho que a antropologia dos índios sul-americanos está sendo lida, mais lida do que nunca, e o exemplo mais dramático disso é o trabalho de Eduardo Viveiros de Castro (I996) sobre o perspectivismo. Não faz muito tempo, um número especial do jornal Inner Asia foi dedicado ao perspectivismo, e muitos pesquisadores que trabalham na Mongólia e na Sibéria estão interessados em comparar essas regiões com a Amazônia. ${ }^{5}$ Vejo, portanto, muito potencial para contribuições oriundas da etnologia indígena sul-americana. Os livros sobre as sociedades de casa e sobre a troca, a respeito dos quais já falamos, também foram influentes nesse sentido. Outro exemplo é o trabalho de Philippe Descola, em particular o livro Par-delà nature et culture (Descola, 2005), que traz uma reflexão sobre animismo, perspectivismo e totemismo. São obras que vêm sendo muito lidas na Inglaterra e em outros países. 
Cursos sobre a etnografia da Amazônia se tornaram parte do currículo. Hoje em dia vemos muitos anúncios de postos para pessoas que trabalham com antropologia sul-americana, o que na minha época seria inconcebível. O ponto importante é que o Brasil vem ocupando muito espaço no cenário internacional. Quando comemoramos o centenário de Lévi-Strauss, muitos brasileiros voaram para cá a fim de se juntar a antropólogos britânicos nesses eventos. Os centros de gravidade da antropologia estão mudando. Ela deixou de ser tão centrada na Inglaterra, na França e nos EUA, e isso é muito bom. As pessoas estão lendo os antropólogos brasileiros, e eles se tornam conhecidos no cenário internacional. Então, creio que os índios da Amazônia estão contribuindo como inspiração teórica, assim como houve uma fase nos anos I950 e I960 em que a onda era a África e a teoria das linhagens, e nos anos I970 e ig80 os melanésios e a teoria da troca. Com efeito, nos últimos dez ou I5 anos, a Amazônia veio se tornando importante em termos tanto etnográficos quanto teóricos. Veja a contribuição do perspectivismo ou daquela parte da etnologia amazônica que chamamos de perspectivista. Há algumas características muito peculiares do pensamento e da cultura dos índios da Amazônia que têm despertado interesse mundo afora, algumas já sinalizadas por Lévi-Strauss e que agora vêm ganhando reconhecimento mais amplo. Os antropólogos amazonistas foram os pioneiros no estudo do corpo, que posteriormente veio a se tornar muito popular na antropologia geral. Os trabalhos de Terence Turner (I969, I994, I995), por exemplo, foram muito influentes de um modo geral.

Então, para sintetizar, eu responderia que a etnologia amazônica atingiu definitivamente sua maturidade no contexto antropológico internacional convencional. Isso é muito positivo. Eu observava a antropologia ir se tornando decadente e fico feliz que o mundo tribal volte ao seu imaginário. Sou completamente a favor de uma antropologia eclética que seja aplicada tanto à antropologia da ciência quanto à antropologia dos povos tribais. Leio tudo com interesse e não creio que a antropologia deva se restringir ao mundo tribal. $\mathrm{O}$ que me deixa desapontado é que, justamente no momento em que os povos amazônicos superam a situação de risco de etnocídio, agora que têm espaço político para sobreviver e prosperar, no exato momento em que começam a recuperar, celebrar e usar sua própria cultura como instrumento de luta política, uma boa parte dos antropólogos declara que eles estão acabando, que eles estão liquidados. A celebração politicamente correta da antropologia por várias razões se voltou contra os povos nativos, no momento em que os povos nativos de fato deixaram de se voltar contra suas próprias culturas e poderiam cooperar muito com os antropólogos. Há tendências na antropologia que desconsideram o mundo tribal como sendo irrelevante, desinteressante e acabado. Não penso nesses termos de forma alguma.

Há ainda outro ponto. Usei o termo antropologia convencional advertidamente, para me referir a um tipo clássico de antropologia, que vem sendo 
ensinado nas universidades britânicas até recentemente. Enquanto isso, entretanto, há coisas acontecendo, como a mudança climática e a destruição ecológica, coisas muito sérias, que os antropólogos vão ter que levar em conta. As pessoas com quem eu trabalhei na Amazônia estão na linha de frente de debates relevantes a respeito desses temas. Sempre me intrigou a questão da relevância, da relação entre antropologia e relevância, e do teor político dessa relação. Que partes da antropologia são ou não relevantes? É curioso como as pessoas fazem uso de alegações políticas para justificar seus gostos e suas próprias posições e para denegrir posições alheias. Por vários motivos, a antropologia da Amazônia me parece extremamente relevante - tanto por razões intelectuais, pois ela pode contribuir com ideias, quanto pelo fato de termos atingido um patamar que nos coloca em posição de compreender a civilização amazônica. Quando lemos que uma nova tribo isolada foi descoberta no Acre ou no Rio Javari, e vemos as imagens aéreas de uma aldeia remota, podemos dar a devida dimensão antropológica a esse fato, coisa que não estaríamos em condições de fazer há 30 anos, porque sabíamos muito menos do que sabemos hoje. Saberemos que, se eles vivem no Javari, devem ser de língua pano, saberemos qual é o seu sistema de parentesco, o que eles comem etc. Não precisamos visitá-los, podemos deixá-los em paz. Do ponto de visto etnográfico estrito, as chances de encontrarmos novidades são muito reduzidas. Se soubermos que há índios sem contatos na Colômbia, saberemos por alto quem eles são, porque já sabemos muita coisa sobre a civilização amazônica.

C.G. Estamos chegando ao fim da entrevista. Você gostaria de fazer um último comentário ou reflexão?

S.H-J. Gostaria de fazer duas observações. Em primeiro lugar, vale dizer que uma das coisas que me apraz na antropologia que pratico é o seu caráter internacional. Uma das alegrias de trabalhar na Amazônia é que tive que aprender francês, espanhol e português. Tenho contatos no Brasil, contatos na Colômbia. Há uma rede internacional muito ampla, e eu acho isso muito bom. Não estou me gabando, mas eu realmente notei que essa é uma experiência bastante específica, essa intensa relação internacional, não é assim para muitos dos meus colegas de departamento. O segundo comentário que quero fazer remete novamente à sua pergunta a respeito da mudança: quem mudou, os Barasana ou eu mesmo? Não pretendo ficar aqui enfatizando o aspecto romântico de minha experiência na Amazônia, mas devo dizer que eu mudei muito. Não vejo o tradicional e o moderno como instâncias separadas, meu interesse é tentar integrá-los. Muito do meu trabalho é sobre isso. Quando escrevi o artigo sobre escambo, eu estava de fato tentando mostrar que essa divisão entre o mundo de ontem e o mundo de hoje é incompleta, é fictícia. Recentemente escrevi um artigo sobre os livros da Coleção Narradores Indígenas do Rio Negro (Hugh-Jones, 20I0), e meu argumento é que os livros são transformações de objetos 
cerimoniais. Antigamente, as pessoas tornavam pública sua reputação durante as cerimônias denominadas Dabucuris. Agora elas o fazem publicando livros, porque não há mais Dabucuris. Os livros são objetos cheios de palavras, exatamente como os objetos. Jurupari não são apenas flautas e trombetas, porque trazem anexada a narrativa mitológica. E é por isso que o meu Jurupari é diferente do seu Jurupari, assim como o meu livro é diferente do seu. Livros são objetos com palavras dentro, e os Jurupari são objetos com palavras anexadas. Interesso-me pelas continuidades. Então, estava usando os livros como fontes de exemplos etnográficos para uma reflexão sobre os objetos e de repente veio a revelação: os livros são esses objetos!

Interesso-me pela forma como a sociedade do Uaupés está se transformando e nesse sentido gostei muito de ler o trabalho de Geraldo Andrello (2006), Cidade do índio. É interessante porque Andrello mostra como as avaliações de hierarquia clânica estão criteriosamente implicadas na política contemporânea. Da mesma forma, em De volta ao Lago de Leite (Lasmar, 2005), vemos como a etnografia tradicional pode ser usada como ponto de partida para o entendimento do que se passa em uma grande cidade como São Gabriel da Cachoeira. E novamente voltamos ao mesmo ponto. Os antropólogos pós-modernos diriam que aquele mundo tribal está acabando, que ele não é interessante, e que temos que estudar a modernidade. Ora, mas você pode estudar a modernidade pela perspectiva dos índios.

E permitam-me apenas uma última observação, que traz de volta o tema da minha infância e do meu desejo de viver com os índios. Uma coisa que me deu imenso prazer estético foi, há bem pouco tempo, tomar um avião e voar para o Pirá-paraná. Entrar pela porta de uma casa e saber como me comportar. Eu me senti totalmente em casa, conhecia as pessoas, eu os conheci por toda a vida, foi como ir ver amigos na Escócia ou algo assim. Nada é estranho para mim, e nunca deixo de me deleitar com o fato de isso ter se tornado possível. No Pirá-paraná deixei de ser um antropólogo, e agora sou o Stephen, foi isso o que mudou. Posso ser absolutamente sincero com eles. Eu disse a eles que tudo isso era muito prazerosos para mim e eles entenderam. Tenho tido conversas intelectuais muito interessantes com os kumus. Um deles estava interessado em entender o que eram conceitos! E eu expliquei a ele a diferença entre abstrato e concreto, porque ele queria adquirir uma linguagem que lhe permitisse explicar o pensamento dos Barasana. E ele me contou duas histórias. Uma história sobre um homem que se casou com uma mulher-estrela, caída do céu. O problema do casal é que ela acorda ao entardecer, pois o entardecer é a sua manhã. Mas quando ela acorda, ele está indo dormir. Tudo gira em torno do fato de as estrelas viverem num mundo diferente. A segunda história era sobre uma mulher cujo marido morre. Ela vai procurá-lo e o encontra no mundo dos mortos. O marido pede que ela busque uma caçarola no rio e ela não consegue achar a caçarola, pois no rio só consegue ver uma cobra. Ele diz a ela: "você é 
tão burra." E vai até o rio e traz ele mesmo a caçarola. Perguntei ao kumu as razões de ter me narrado essas duas histórias. "Porque eu quero saber como você as chamaria, do que elas tratam?", ele respondeu. E eu retruquei, "Isso se chama perspectivismo, elas são sobre perspectivas". E ele disse: "Essa é a palavra que eu quero, essa é a palavra que eu quero! Eu queria ser capaz de falar sobre o princípio que está por trás dessas histórias". E então eu disse a ele que foi, para mim, um grande prazer ser capaz de vir do meu mundo, chegar em sua casa, comer sua comida, falar sua língua, conhecendo-o tão bem, e que isso para mim era muito gratificante. Que era como se deixasse de ser inglês e passasse a ser barasana. Disse a ele que era como trocar de roupa. E ele me disse: "Não, você troca é de perspectiva"! É esse nível de engajamento intelectual que considero o mais interessante. Depois dessa conversa, eu trabalhei com ele sobre benzimentos. Os índios às vezes brincavam comigo, dizendo que eu já era um kumu, que eu conhecia várias rezas, e essas coisas. Então eu fiz questão de dizer a ele que eu nunca usaria os benzimentos, nunca os ativaria, pois meu interesse era exclusivamente entender como os Barasana pensam. E então esse homem disse: "quando você vem aqui, você muda de perspectiva, e é por isso que você é um kumu". Ou seja, ele usou uma ideia de Eduardo Viveiros de Castro, que discutimos durante a nossa conversa intelectual, para fazer piada comigo. Isso é muito divertido!

C.G. É como voltar à Jamaica, onde você passou a infância, e estar de novo em casa.

S.H-J. Exatamente.

Concedida em fevereiro de 2009 (Cambridge) e março de 2012 (Rio de Janeiro) | Aprovada em I6/Io/20I5 
Cristiane Lasmar é antropóloga, doutora pelo Museu Nacional (UFRJ) e pós-doutora pela Fondation Maison de Sciences de L'Homme. Tem longa experiência de pesquisa junto aos grupos indígenas do alto Rio Negro, com quem trabalha desde I995, tendo atuado como assessora da Federação das Organizações Indígenas do Rio Negro e do Instituto Socioambiental no município de São Gabriel da Cachoeira (AM). Autora do livro De volta ao Lago de Leite: gênero e transformação no Alto Rio Negro (2005), premiado com a Menção Honrosa no Concurso Anpocs de Obras Científicas de 2006. Atualmente é pesquisadora autônoma atuando na área da antropologia da infância, família e educação.

Cesar Gordon é professor do Departamento de Antropologia Cultural e do Programa de Pós-graduação em Sociologia e Antropologia do IFCS-UFRJ, e doutor pelo Museu Nacional (UFRJ). Em 2008-2009 foi professor convidado na posição de maître de conférence associé do Collège de France (Paris), vinculado à cadeira antropologia da natureza e ao Laboratoire d'Anthropologie Sociale (LAS-EHESS). Realiza pesquisas com os índios Xikrin e Kayapó da Amazônia (Pará) desde I998. É autor do livro Economia selvagem: ritual e mercadoria entre os índios Xikrin-Mebengokre (2006), premiado no concurso Anpocs de 2007 como Melhor Obra Científica em Ciências Sociais. 


\section{NOTAS}

I Os termos homossubstituição e heterossubstituição, utilizados por Philippe Descola no capítulo mencionado na nota anterior, foram cunhados por Maurice Godelier em The making of great men: male domination and power among the New Guinea Baruya, publicado emI986, e delimitam dois regimes de troca encontrados em sociedades melanésias: no primeiro, uma pessoa humana só pode ser trocada por outra pessoa humana (como no caso dos intercâmbios matrimoniais e na guerra); no segundo, uma pessoa humana pode ser substituída por animais ou coisas (como no caso em que se paga um valor material para obtenção de uma noiva ou uma compensação econômica para desagravar um homicídio). No artigo em questão, Descola argumenta que este último tipo de troca (heterossubstituição) praticamente não ocorre nas sociedades amazônicas, nas quais não haveria "preço da noiva" (bridewealth), e sim "serviço da noiva" (brideservice), e um homicídio é sempre pago com outro homicídio. A distinção entre sociedades de preço da noiva e sociedades de serviço da noiva foi desenvolvida teoricamente por Jane Collier e Michelle Rosaldo no bem conhecido artigo "Politics and gender in simple societies", publicado em Ortner \& Whitehead (I98I).

2 Coleção de livros publicada pela Federação das Organizações Indígenas do Rio Negro (FOIRN) em parceria com o Instituto Socioambiental (ISA). Cada livro apresenta uma versão das narrativas da origem, da mitologia e da história mais recente de um grupo particular da bacia do Rio Negro, como os Desana, Tukano, Tariana ou Baniwa, mas sempre do ponto de vista de um clã específico.

3 "Duturo", corruptela de doutor, é o termo usado pelos índios do Uaupés para se referir aos brancos com alto grau de instrução, principalmente aos pesquisadores que frequentam a região.

4 Organização não governamental colombiana que trabalha em parceria com a Acaipi.

5 Trata-se do volume 9, número 2 de 2007 da revista Inner Asia, editado por Caroline Humphrey, Rebecca Empson e Morten A. Edersen. Ver também Brightman, Grotti \& Ulturgasheva (20I2). 


\section{REFERÊNCIAS BIBLIOGRÁFICAS}

Andrello, Geraldo. (2006). Cidade do índio: transformações e cotidiano em Iauareté. São Paulo: ISA/NuTI/Ed. Unesp.

Brightman, Mark; Grotti, Vanessa \& Ulturgasheva, Olga (orgs.). (2012). Animism in rainforest and tundra. Oxford: Berg. Chagnon, Napoleon. (1992). Yanomamo: the last days of Eden. Nova York: Harcourt Brace Jovanovich.

Chagnon, Napoleon. (I968). Yanomamo: the fierce people. Nova York: Holt, Rinehart and Winston.

Descola, Philippe. (2005). Par-delà nature et culture. Paris: Gallimard (Bibliotèque des Sciences Humaines).

Descola, Philippe. (200I). Genres of gender: local models and global paradigms in the comparison of Amazonia and Melanesia. In: Gregor, Thomas \& Tuzin, Donald (orgs.). Gender in Amazonia and Melanesia: an exploration of the comparative method. Berkeley, University of California Press, p. 9II I 4 .

Gillison, Gillian. (1993). Between culture and fantasy: a New Guinea highlands mythology. Chicago: University of Chicago Press.

Gordon, Cesar. (2006). Economia selvagem: ritual e mercadoria entre os índios Xikrin-Mebêngôkre. São Paulo: ISA/NuTI/Ed. Unesp.

Heckenberger, Michael et al. (2008). Pre-Columbian urbanism, anthropogenic landscapes, and the future of the Amazon. Science, 32 I, p. I 2 I 4-I 2 I 7.

Hugh-Jones, Christine. (1979). From the Milk River: spatial and temporal processes in Northwest Amazonia. Cambridge: Cambridge University Press.

Hugh-Jones, Stephen. (2013). Bride-service and the absent gift. Journal of the Royal Anthropological Institute, I92, p. 356377.

Hugh-Jones, Stephen. (20I0). Entre l'image et l'écrit: la politique tukano de patrimonialisation en Amazonie. Cahiers des Amériques Latines, 63/4, p. I95-227.

Hugh-Jones, Stephen. (2009). The fabricated body: objects and ancestors in Northwestern Amazonia. In: Santos-Granero, Fernando (org.). The occult life of things: native Amazo- 
nian theories of materiality and personhood. Tucson: University of Arizona Press.

Hugh-Jones, Stephen. (200I). The gender of some Amazonian gifts: an experimente with an experiment. In: Gregor, Thomas \& Tuzin, Donald (orgs.). Gender in Amazonia and Melanesia: an exploration of the comparative method. Berkeley: University of California Press, p. 245-278.

Hugh-Jones, Stephen. (I997). Amazonia; Tukano (Vaupés). In: Oliver, Paul (org.). Encyclopedia of vernacular architecture of the world. Cambridge: Cambridge University Press, p. I636I637.

Hugh-Jones, Stephen. (I995). Inside out and back to front: the androgynous houses in Northwest Amazonia. In: Carsten, Janet \& Hugh-Jones, Stephen (orgs.). About the house: Lévi-Strauss and beyond, p. 226-269.

Hugh-Jones, Stephen. (I993). Clear descent or ambiguous houses? A re-examination of Tukanoan social organization. L'Homme, 33/I 26-I 28, p. 95-I 20.

Hugh-Jones, Stephen. (I992). Yesterday's luxuries, tomorrow's necessities: business and barter in Northwest Amazonia. In: Humphrey, Caroline \& Hugh-Jones, Stephen (orgs.). Barter, exchange and value: an anthropological approach. Cambridge: Cambridge University Press p. 42-74.

Hugh-Jones, Stephen. (I988). The gun and the bow: myths of white men and Indians. L'Homme, 28/I06-I07, p. I38-I55.

Hugh-Jones, Stephen. (1979). The palm and the pleiades: initiation and cosmology in Northwest Amazonia. Cambridge: Cambridge University Press.

Hugh-Jones, Stephen \& Carsten, Janet. (I995). About the house: Lévi-Strauss and beyond. Cambridge: Cambridge University Press.

Humphrey, Caroline \& Hugh-Jones, Stephen. (I992). Barter, exchange and value: an anthropological approach. Cambridge: Cambridge University Press.

Malinowski, Bronislaw. (1954) [1926]. Myth in primitive psychology. In: Magic, science and religion and other essays. Garden City, NY: Doubleday \& Co., p. 93-I48.

Lasmar, Cristiane. (2005). De volta ao Lago de Leite: gênero e transformação no Alto Rio Negro. São Paulo: ISA/NuTI/Ed. Unesp. 
Lasmar, Cristiane \& Gordon, Cesar. (20I4). A formação de um etnólogo: entrevista com Stephen Hugh-Jones. R@u, 6/I, p. 2 17-228.

Lea, Vanessa. (I986). Nomes e nekrets Kayapó: uma concepção de riqueza. Tese de Doutorado. PPGAS/Museu Nacional-UFRJ. Lévi-Strauss, Claude. (I979). La voie des masques. Paris: Plon. Lévi-Strauss, Claude. (1956). As organizações dualistas existem? In: Antropologia estrutural. Rio de Janeiro: Tempo Brasileiro, p. I48-I80.

McKinnon, Susan. (1995). Houses and hierarchy: the view from a South Mollucan society. In: Carsten, Janet \& HughJones, Stephen (orgs.). About the house: Lévi-Strauss and beyond, p. I70-I88.

Ortner, Sherry B. \& Whitehead, Harriet (orgs.). (I98I). Sexual meanings: the cultural construction of gender and sexuality. Cambridge: Cambridge University Press, p. 275-329.

Overing, Joanna. (1975). The Piaroa: a people of the Orinoco Basin: a study in kinship and marriage. Oxford: Clarendon Press. Overing, Joanna. (1972). Cognation, endogamy and teknonymy: the Piaroa example. South Western Journal of Anthropology, 28, p. 282-297.

Overing, Joanna \& Passes, Alan (orgs.). (2000). The anthropology of love and anger: the aesthetics of conviviality in native America. Londres: Routledge.

Strathern, Marilyn. (I988). The gender of the gift: problems with women and problems with society in Melanesia. Berkeley: University of California Press.

Turner, Terence. (I995). Social body and embodied subject: bodiliness, subjectivity and sociality among the Kayapó. Cultural Anthropology, Io/2, p. I43-79.

Turner, Terence. (I994). Bodies and anti-bodies: flesh and fetish in contemporary social theory. In: Csordas, Thomas (org.). Embodiment and experience. Cambridge: Cambridge University Press, p. 27-47.

Turner, Terence. (1969). Tchikrin: a Central Brazilian tribe and its symbolic language of bodily adornment. Natural History, 78 , p. 50-70. 
Viveiros de Castro, Eduardo. (I996). Os pronomes cosmológicos e o perspectivismo ameríndio. Mana, 2/2, p. I I5-I44. Viveiros de Castro, Eduardo. (I993). Alguns aspectos da afinidade no dravidianato amazônico. In: Viveiros de Castro, Eduardo \& Cunha, Manuela Carneiro da (orgs.). Amazônia: etnologia e história indígena. São Paulo: Edusp/Fapesp, p. I502 IO. 


\section{UM ANTROPÓLOGO DA CIVILIZAÇÃO AMAZÔNICA: ENTREVISTA COM STEPHEN HUGH-JONES}

\begin{abstract}
Resumo
Nesta entrevista Stephen Hugh-Jones faz um balanço do campo da etnologia indígena na Amazônia e de seu próprio trabalho em parceria com Christine Hugh-Jones junto aos índios de língua tukano oriental da bacia do Uaupés. Dialogando com alguns dos principais autores americanistas, enfatiza a necessidade de que os modelos antropológicos de descrição dos povos ameríndios levem em conta a complexa variedade de suas formações sociais e cosmológicas. Destaca as especificidades etnográficas da região do noroeste amazônico, que considera uma autêntica civilização, e reafirma sua confiança na vocação da antropologia da Amazônia para produzir sínteses teóricas renovadas e comparativas, que contemplem a riqueza sociocultural e histórica desses povos e contribuam para o pensamento antropológico de maneira geral.
\end{abstract}

\section{THE ANTHROPOLOGY OF AMAZONIAN CIVILIZATION: AN INTERVIEW WITH STEPHEN HUGH-JONES}

In this interview, Stephen Hugh-Jones takes stock of his work, in collaboration with Christine Hugh-Jones, among the Eastern Tukanoan speakers of the Uapés basin, and of Amazonian ethnology more generally. In dialogue with some of the main Americanist authors, he stresses that anthropological models of Amerindian peoples need to account for the complex variety of social and cosmological forms found in the continent. He highlights the ethnographic specificities of northwestern Amazonia, which he considers to be a veritable civilization, and reaffirms his conviction that Amazonian anthropology is capable of producing renewed and comparative theoretical syntheses which take into account the sociocultural and historical wealth of the region's people, hence contributing to anthropological thought more generally.
Palavras-chave

Antropologia;

Índios;

Amazônia;

Civilização;

História.

Keywords

Amazonia;

Amerindians;

Anthropology;

Civilization;

History. 